\title{
Managing Volunteer Programs: Reporting Volunteer Contributions ${ }^{1}$
}

Robert R. Meadows, Marilyn K. Lesmeister, and Marilyn N. Norman ${ }^{2}$

\section{Why are volunteer programs important?}

Volunteers working in community programs make a difference in many neighborhoods, counties, and states. But, the value of a volunteer program is sometimes overlooked. Documenting the value of volunteer programs helps to celebrate success today and promote growth in the future. The manager of a volunteer program is in a good position to monitor and report the success and value of that program.

\section{Who needs to know?}

The value of a program includes its goals and impacts. Non-profit organizations need to talk about their goals and impacts to their customers, advisory committees, and boards of directors. These groups are called stakeholders.

Another stakeholder is a funding partner. A funding agency wants to know how their financial contribution is having an impact. When considering the level of financial resources that are directed to an organization, department or program, it is vital that communication back to that stakeholder is not taken for granted.

\section{What information is important?}

Every volunteer project has value and can be documented. Participants in volunteer programs take action and make improvements in the lives of others, but these efforts may not be documented or reported to its members or its stakeholders.

Volunteer groups make many varied contributions in communities across the nation each year. Examples include: 4-H members working beside Department of Health staff to conduct fitness programs in elementary schools; or Boy and Girl Scouts reading to pre-schoolers at the library; or Community Club members painting homes that have been repaired after a hurricane. Many volunteer contributions and hours provide financial, educational, social and emotional benefit to many. The value of volunteer programs be documented by both narrative information and numbers.

1. This document is FCS9239, one of a series of the Family Youth and Community Sciences Department, Florida Cooperative Extension Service, Institute of Food and Agricultural Sciences, University of Florida. Original publication date March 1, 2006. Visit the EDIS Web Site at http://edis.ifas.ufl.edu

2. Robert R. Meadows, 4-H Associate Director, Virginia Tech, Blacksburg, Virginia, 24061, Marilyn K. Lesmeister, 4-H Volunteer Development Specialist, Department of Family, Youth and Community Science, and Marilyn N. Norman, Associate Professor in Family, Youth and Community Sciences and Florida 4-H State Program Leader, Gainesville, FL 32611.

The Institute of Food and Agricultural Sciences (IFAS) is an Equal Opportunity Institution authorized to provide research, educational information and other services only to individuals and institutions that function with non-discrimination with respect to race, creed, color, religion, age, disability, sex, sexual orientation, marital status, national origin, political opinions or affiliations. U.S. Department of Agriculture, Cooperative Extension Service, University of Florida, IFAS, Florida A. \& M. University Cooperative Extension Program, and Boards of County Commissioners Cooperating. Larry Arrington, Dean 


\section{Narrative documentation}

A wealth of narrative information can be collected through watching and listening (Schatzman $\&$ Strauss). Volunteers can provide reflective quotes on written evaluation forms or during brief interviews at an activity. Community citizens or members of a partner organization can provide valuable information when they experience the results of volunteer service.

\section{Numerical documentation}

To help document statistical results, a major national source provides information about the financial value of time. Since, 1980, Independent Sector has been a nonpartisan coalition of organizations that supports research, promotes policy and develops resources for advancing the common good across the nation. Annually, Independent Sector provides national guidelines to calculate the financial value of adult volunteer time.

The value of volunteer time is based on the average hourly earning of all production and non-supervisory workers on private, nonfarm payrolls... Independent Sector takes that figure and increases it by 12 percent to estimate the fringe benefits (February 2006).

In 2005, Independent Sector determined that the national average of volunteer time was valued (salary and fringe benefits) at $\$ 18.04$ per hour.

Independent Sector also uses statistics available from the United States Bureau of Labor to calculate individual state values of volunteer time. For example, Florida's 2005 equivalent value (salary and fringe benefits) for adult volunteer time was $\$ 15.43$. In January 2006, the minimum wage in Florida became $\$ 6.40$. This number is appropriate for calculating the value of youth volunteer time.

\section{How to calculate value of time in Florida}

To calculate the value of volunteer time in Florida, first identify the number of participants and the total (or average) number of hours contributed. a) Multiply the number of youth by the total number of hours then multiply by $\$ 6.40$.

For example:

Multiple 46 youth by the 12 hours each youth contributed $=552$ total hours contributed.

Then multiple 552 hours by $\$ 6.40=$ $\$ 3,532.80$ value of time contributed by youth.

b) Multiply they number of adult volunteers by the total number of hours then multiply by $\$ 15.43$.

For example:

Multiple 8 adult volunteers by the 15 hours each contributed $=120$ total hours contributed.

Then multiply 120 hours by $\$ 15.43=$ $\$ 1,851.60$ value of time contributed by adults.

\section{Reporting time contributions with financial impact}

Once the financial value of volunteer time is known, it is important to communicate that information to stakeholders, including: advisory boards, funders, and the volunteers themselves. Here are two brief examples that may be printed in a letter, newsletter, news article or grant application.

\section{Example 1}

During the month of November, the Gunther Greats conducted a canned food drive for the hungry. A total of 139 youth spent five hours per person, collecting cans of food. A total of 38 adult volunteers dedicated an average of six hours per person, to this project. Together, they collected 1,032 cans of food. This area project donated food to 236 families. Young people contributed 695 hours and adult volunteers contributed 228 hours of work, with a total monetary value of $\$ 7,966.04$. In addition, the local food bank saved an additional \$2,000 that would have been spent if volunteers had not collected necessary food products. Total contribution to the community would include both the value of the time and the collected can goods $(\$ 7,966.04+\$ 2,000)$. 


\section{Example 2}

The Community Pride Club decided to become involved in a county-wide project to improve the quality of water streams. A total of 132 adult volunteers and 697 youth volunteers were involved. By keeping time sheets recording the number of volunteer hours contributed, the data showed that 132 adult volunteers contributed 2,158 hours ( 84 people dedicated 13 hours; 10 gave 25 hours; 27 gave 17 hours; 9 gave 15 hours; and, 11 people gave 9 hours). Youth volunteers contributed 8,300 hours (325 youth dedicated 10 hours; 140 youth gave 12 hours; 222 gave 15 hours; and 10 youth gave 4 hours). Young people and adult volunteers contributed a total of 10,458 hours of work, with a monetary value of $\$ 86,417.94$. This had a tremendous impact on the community.

An oversized version of a "check" written for the amount of $\$ 86,417.94$ could accompany this report when it is presented to a major stakeholder, such as, Water Management District.

\section{Example of a full report to a funding source}

This year, the 4-H Volunteer Association made the decision to become involved in a county-wide effort to improve and protect water quality. Of the five overall tasks to be accomplished by Grand County, the 4-H Volunteer Association accepted the challenge of removing man-made debris from five streams. The 4-H members agreed to work with the Volunteer Association in this community service project.

Team captains (youth) and co-captains (adults) were selected from each of the five communities where streams exist. The captains recruited members and volunteers from each of the twelve county 4-H clubs. County employees worked with the Team Captains to assign specific tasks, and provide special equipment. The project was completed between June 1 and July1, 2006.

A total of 132 adult volunteers gave 2,158 hours, and 697 youth gave 8,300 hours to this project. A total of 10,458 volunteer hours were contributed. The value of youth volunteers ( $\$ 6.40 @$ hour) and adult volunteers ( $\$ 15.43 @$ hours) is $\$ 86,417.94$ to Grand County.

The impacts of this project are that:

- Every youth and adult volunteer contributed approximately two days to clean a stream.

- Youth and adults worked together to make five streams cleaner and safer.

- A total of eight tons of debris were removed from five streams.

- $98 \%$ of all volunteer members and adults expressed willingness to assist in developing and/or promoting educational programs for keeping streams clean in the future.

- $86 \%$ of community residents living along the five streams expressed interest in learning more about water quality and the value of clean streams.

- $97 \%$ of youth and adult volunteers are willing to become involved in future projects that improve the lives of people in their community.

Other impacts are stated by participants and community residents. They said:

- "It's a great feeling to know that we are making a difference in the place where we live. I want to help in other ways too," (4-H Member, 2007).

- "This was no easy task, and I worried a little about running into snakes or getting bit by one. However, the junk we removed from one stream alone, would fill three dump trunks! The streams look great now. They will be cleaner and safer for drinking water, for wildlife, and for recreation," (4-H Volunteer, 2007).

- "The stream in my community looks better than it ever has in the past ten years I have lived here. Thank you 4-H clubs in Grand County, for caring about water quality and my community," (Grand County Resident, 2007). 
This project ensures that residents and visitors can enjoy the real beauty of our streams. The balance of nature remains intact without the negative consequences of human neglect. And, future generations in this area will benefit from having a clean, safe source of drinking water.

\section{Conclusion}

Stakeholders such as advisory committees and boards of directors want to know about successful programs that can be acknowledged and celebrated. These stakeholders promote the organization, its mission, and future programs.

Current funding stakeholders want to know that their contributions are having an impact. They may be willing to contribute again. Funding partners may provide new resources and make additional donations when they hear the facts connected with a successful program.

Future participants and new volunteers are attracted to a successful program. Documentation using narrative and numerical data can be used when marketing the volunteer program.

\section{References}

Schatzman, Leonard and Strauss, Anselm L. (1973.) Field research: Strategies for a natural sociology. Prentice-Hall: Englewood Cliffs, NJ.

Lewis, Barbara A. (1998.) The Kid's Guide to Social Action. Free Spirit: Minneapolis, MN.

Independent Sector (2005.) http://www.independentsector.org/programs/research/ volunteer_time.html 